\title{
Rosa Einhorn (1872-1950): A Woman Pioneer in Medicine between Bosnia (1902-1913), New York, and Palestine
}

\author{
Brigitte Fuchs ${ }^{1}$, Husref Tahirović ${ }^{2}$ \\ ${ }^{1}$ Department of Cultural and Social Anthropology at the University of Vienna, Vienna, Austria, ${ }^{2}$ Department of Medical \\ Sciences of the Academy of Sciences and Arts of Bosnia and Herzegovina, Sarajevo, Bosnia and Herzegovina \\ Correspondence: brigitte.fuchs@univie.ac.at; Tel.: + 43650640 5150; Fax.: + 431427749533 and husref.tahirovic@untz.ba; \\ Tel./Fax.: + 38735303740
}

Received: 30 November 2020; Accepted: 25 December 2020

\begin{abstract}
This short biography details the life and medical activities of Rosa Einhorn, mariée Bloch (1872-1950), who practised as an Austro-Hungarian (AH) official female physician in Travnik in occupied Bosnia and Herzegovina (BH) from 1902 to 1904, and as a semi-official private physician from 1905 to 1912/13. Born in Hrodna district in the Russian Pale of Crescent, Einhorn had qualified and practised as a "feldsheritsa" in Russia and went to Switzerland to study medicine in 1896. Upon receiving her medical doctorate from the University of Lausanne in 1901, she became recommended as a particularly adequate candidate for the not-yet-created position of an AH official female physician in BH. After Einhorn functioned as a general practitioner for women and children in Travnik and the adjacent districts for two years, the $\mathrm{AH}$ public health authorities officially dismissed her due to her engagement and marriage to the AH judiciary Sigismund Bloch (1850-1927). However, she obtained a right to private practice in 1905 and was employed as a private physician in AH anti-syphilis campaigning. Struggling for her reinstatement as an official female physician in Travnik, she also strove for the accreditation of her Swiss diploma in Austria, though in vain. After two attempts to emigrate to the United States in 1904 and 1913, Rosa Einhorn finally left Europe to work as a physician in the United States and Mandatory Palestine/Eretz Israel in 1923. She died in New York on May 27, 1950. Conclusion. Rosa Einhorn was employed as a provisory official female physician in Travnik in 1903/1904, the AH authorities accepting her only as a local private female physician after her marriage in 1905. Struggling in vain for her reinstatement, she finally left Bosnia in 1913.
\end{abstract}

Key Words: AH Official Female Physicians • Rosa Einhorn • Travnik • Bosnia and Herzegovina.

\section{Introduction}

In February 1903, a Viennese daily newspaper published a brief report on the medical activities of Rosa Einhorn among Muslim women in Bosnian Travnik and a hand drawing showing "Miss Doctor" at work in her local outpatient ward (Picture 1) (1). Attentive readers may have noticed that the press reported in December 1902 that a "fifth" official female physician had been appointed in Bosnia and Herzegovina (BH) (2). Although Rosa Einhorn is the only Austro-Hungarian $(\mathrm{AH})$ official female physician in $\mathrm{BH}$ who has ever been featured in the German Austrian daily press, a de- tailed biography has never been dedicated to her. The reason for this is not least that Einhorn was dismissed as a still provisory officer in 1904, although official Austrian sources continued to list her as a private physician settled in Travnik (3).

The Czech historian Ctibor Nečas, author of a historical study of the AH extraordinary institution of publicly employed female physicians for Muslim women in $\mathrm{BH}$, briefly mentioned Einhorn as an official female doctor who never acquired permanent status because of her marriage to the locally settled AH judiciary Sigismund Bloch (1850-1927) in 1905 (4). Nečas suggested that Rosa Einhorn, mariée Bloch functioned like 


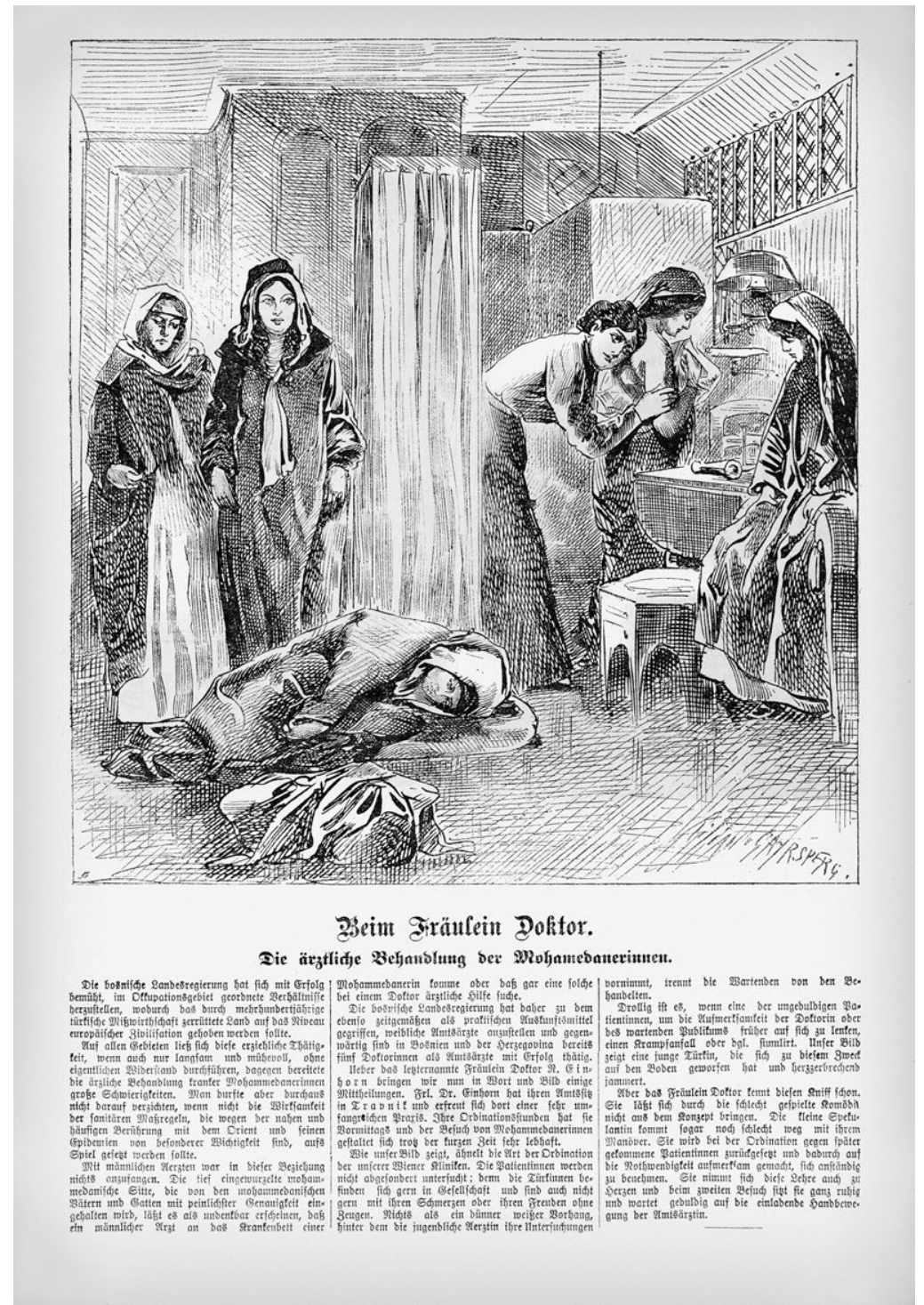

Picture 1. 'At Miss Doctor's. The Treatment of Muslim Women'. Source: Neuigkeitsweltblatt, 19 February 1903, s.p.

Gisela Januszewská in Banja Luka ${ }^{1}$ as a semi-official female physician of Travnik, as she was not replaced with another official. Barbara Martin, who evaluated the $\mathrm{AH}$ sources concerning Einhorn in a grey literature research report (5), revealed that Nečas avoided mentioning the bullying that Ein-

${ }^{1}$ Fuchs B, Tahirović H. Gisela Januszewska (née Rosenfeld), an Austro- Hungarian 'Woman Doctor for Women' in Banjaluka, 1899-1912. Acta Med Acad. 2020;49(1):75-83. [cited 2020 Aug 12]. Available from: https://pubmed.ncbi.nlm.nih. gov/?term $=$ Tahirovic + h\&filter $=$ simsearch 1 .fha horn experienced from the local authorities and $\mathrm{AH}$ physicians in Travnik. When she reacted with a months-long absence over leave from her service, she legitimised her dismissal in November 1904. As soon as she returned in 1905, she married her fiancé and struggled for her reinstatement as an official female physician. Her only success was that she was granted the right to practice as a private physician with a Swiss diploma in BH in 1905 because the provincial public health authorities sought to keep a female physician for syphilis eradication on site $(4,5)$. However, it is uncertain whether the hostility was directed predominantly against Einhorn's person or her office as a modernising agent in which she incorporated and was considered to facilitate the recognition of female physicians in Austria and Hungary.

Against this background, Einhorn's presence and medical practice in Travnik went largely unnoticed by its residents (5). She was mentioned neither in the contemporary Travnik daily press (5) nor in the memories of the local Sephardi, who gave prominence to AH medical institutions and Ashkenazi physicians who came in from 1879 to 1918 , because of their tradition as medical practitioners $(6,7,8,9)$. Few narrative sources exist on Einhorn's life except the documents she and $\mathrm{AH}$ authorities in $\mathrm{BH}$ produced in the outlined conflict. Therefore, the following fragmentary biography of Rosa Einhorn is based in the administrative traces she left, particularly in $\mathrm{BH}$, on her numerous transatlantic passages, and finally, as a physician in the United States and Mandatory Palestine/Eretz Israel. Rosa Einhorn's life and medical activities are the subjects of this review. 


\section{Einhorn's Family Background and Education}

Rosa Einhorn was born on April 24, $1872^{2}$ in Suchowola, then a small city situated in the Russian Pale of Crescent in Hrodna (then Grodno), Belarus, today situated in Eastern Poland. She was the fourth child of local Rabbi Avraham Einhorn (died in 1911) and his wife Sara(h) Hoffmann (10, 11, 12). Among her older siblings was Max Einhorn (1862-1953) (Picture 2) who, after studying medicine in Kiev and Berlin, emigrated to the United States in 1885 and subsequently became one of the most renowned gastroenterologists of his time (13, 14, 15). Max Einhorn noted in an autobiographical sketch published in 1929 that his family lived in materially modest circumstances and that he had to fund his studies himself (13). He is the one who ensured that his younger sisters were able to study at 'German' universities in the 1890s.

Rosa Einhorn attended a girls' gymnasium in Hrodna and took her school-leaving examination with honours in $1889 .{ }^{3}$ Subsequently, she attended medical courses for 'learned midwives' ('uchenye akusherki') at the Military Medical Surgery Academy in St. Petersburg (16). These courses provided a qualification equivalent to a medical degree until 1882 but were downgraded afterwards. In light of the low quota for Jewish students introduced in 1886 to Russian higher and academic education, ${ }^{4}$

${ }^{2}$ When Einhorn petitioned for her US-nationalization in 1928, she gave 1874 as her year of birth; before her US-emigration, she used to give - quite probably correctly - her year of birth as 1872; see "Rosa Einhorn"; New Jersey, U.S., Naturalization Records, 1878-1945. The National Archives at Washington, D.C.; Washington, D.C.; Series Title: Petitions for Naturalization from the U.S. District Court for the District of New Jersey at Newark, New Jersey, 1924-1945; Series Number: M2123; Record Group Title: Records of the Immigration and Naturalization Service, 1787-2004; Record Group Number: 85; NARA Microfilm Number: 040 [Ancestry.com. New Jersey, U.S., Naturalization Records, 1878-1945 Lehi, UT, USA: Ancestry.com Operations, Inc., 2016 [database on-line; cited 2020 Nov. 18].

${ }^{3}$ Rosa Einhorn's petition for reinstatement as an official physician in Travnik from April 23, 1912, ABH, ZMF No. 6212, April 26, 1912.

${ }^{4}$ Both the downgrading of the courses (1882) and the low quota for Jewish students (1886) in Russia contributed to the flow of young women aspiring academic education in Switzerland and,

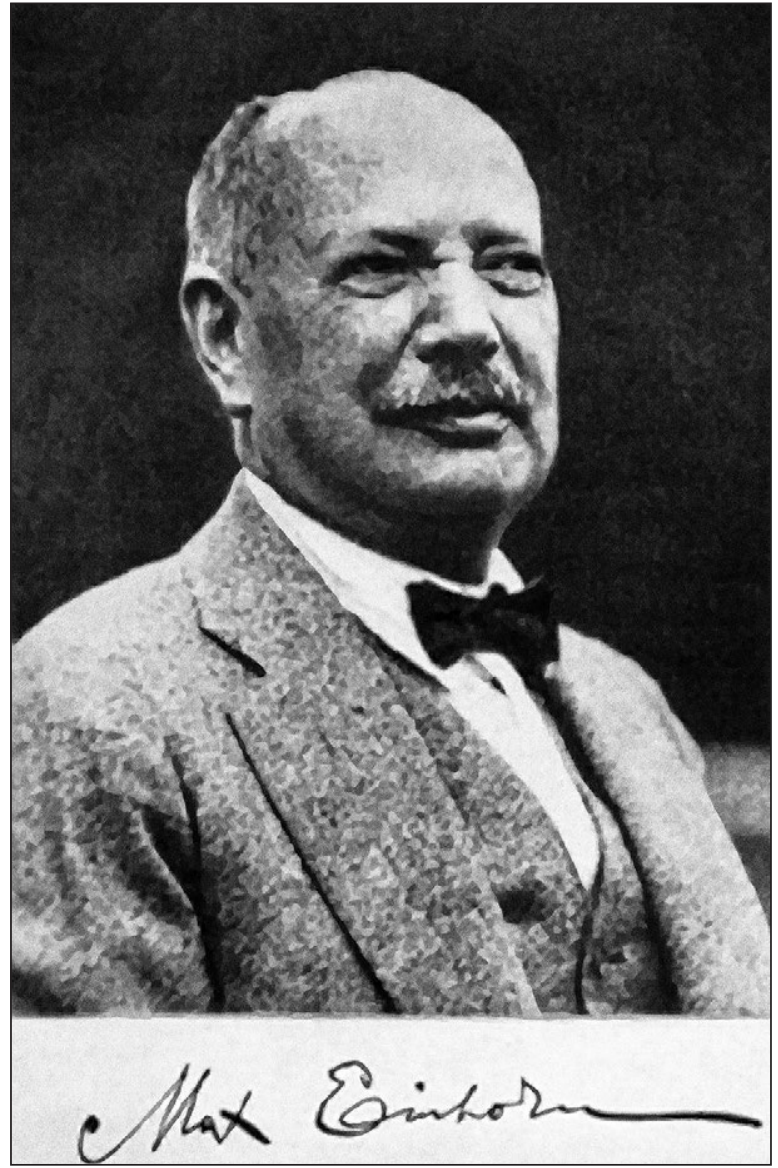

Picture 2. Rosa Einhorn's brother Prof. Dr. Max Einhorn (1862-1953), inventor of surgical instruments, first professor of gastroenterology at the New York Post-Graduate Medical School and Hospital and physician at the then 'German' Lenox Hill Hospital in New York.

Einhorn could not consider studying medicine but passed her midwife exam in December 1892. In the same year, her brother Max was married in New York to Flora Strauss (1863-1934), the US Macy's

after 1900, also in Prussia. According to Daniela Neumann (1987: 75c) the share of Russian-Jewish female students studying at Swiss universities increased from $10 \%$ in the 1870 -s to $60-80 \%$ between 1880 and 1914 (17). The willingness of Eastern Jewish parents to let their daughters acquire an academic qualification (abroad) has been attributed besides a secularized preference for 'studying' to the fact that studying was considered still less expensive than a marriage (dowry), cf. Hirsch 2013 (18). The overrepresentation of Jewish women particularly among female medicine students and physicians in both Prussia and Austria has been demonstrated by Harriet Freidenreich 1996; 2002 (19, 20) and Miriam Offer 2020 (21); for female Jewish students in Germany, see also Grossmann 1994 (22). 


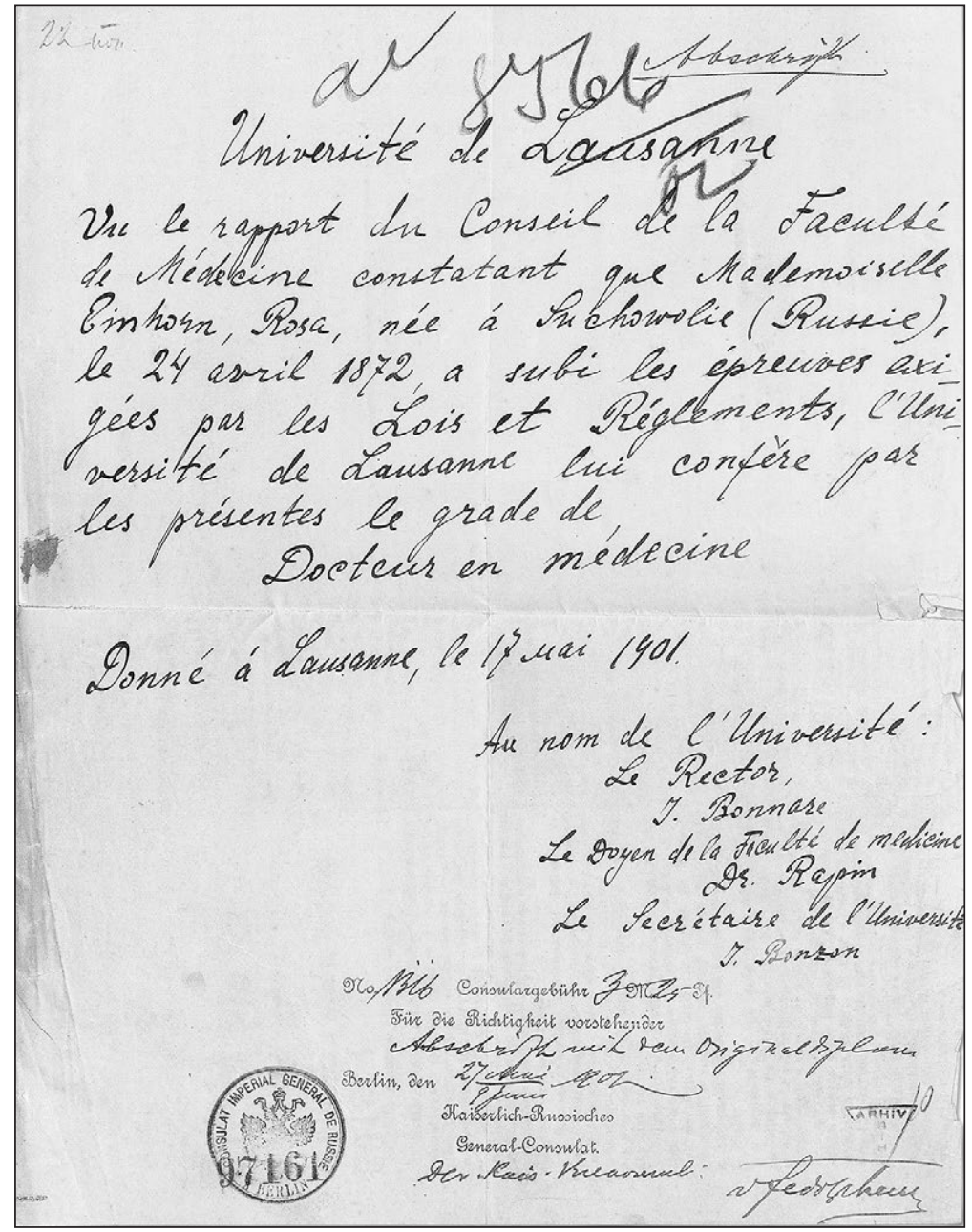

Picture 3. Rosa Einhorn's award certificate of her doctor-title from the University of Lausanne, dated from 17 May 1901. Source: Vgl. ABH, ZVS 1902, Signaturengruppe 52-113, kut. 151 [cited 2020 Nov 2].

department store owner's daughter, thus becoming a wealthy man (15). Einhorn started to study medicine in St. Petersburg, although she was not entitled to graduate as a woman. After completing an internship in two clinics in St. Petersburg, she accepted the strenuous and poorly paid position as a community (zemstvo) "feldsheritsa" (paramedic) in Afanasyeva Sloboda, a rural village in the Oblast of Pskow in north-western Russia in $1895(4,5)$.

Perhaps encouraged by her brother, she gave up her service after one year, with the zemstvo authorities attesting to her 'exemplary diligence and humane demeanour towards patients' (5). In 1896, she and her younger sister Rahel left Russia for
Berlin (18). Einhorn enrolled at the medical faculty of Berlin University and completed another internship at the local ophthalmological clinic (5). Still, in 1896, she moved her medical studies to Berne, Switzerland (16). Einhorn elaborated her thesis on lower limb fractures titled "Beitrag zur Kenntnis der Unterschenkelfracturen" (23) at the University Clinic of Berne under the auspices of its director, the Swiss surgeon Theodor Kocher (1841-1917). Based on the clinic's collection of lower limb fractures, she developed analytically impressive systematics published also in Archiv für klinische Chirurgie (1901) (24). However, she did not finish her studies in Berne but enrolled at the University of Lausanne (25) in the spring of 1900 , where she received her doctorate on May 17, 1901 (Picture 3).

She could not turn her preference for orthopedic surgery, which she might have practiced as a "feldsheritsa", into a career, however. Upon finishing her studies, Rosa Einhorn completed numerous internships at various clinics and hospitals first in Berlin, ${ }^{5}$ then in Vienna (5). Among others, she volunteered at the dermatological clinic of Vienna University where she met the head Professor Isidor Neumann (1832-1906) (5). Neumann was the consultant for syphilis eradication at the 'Bosnian Bureau' the supreme authority of $\mathrm{BH}$ at the $\mathrm{AH}$ Ministry of Finance - and was the first to recommend the use of female doctors for this purpose. Neumann's recommendation was taken up by the AH Minister of Finance and governor of BH, Beni de Kállay,

${ }^{5}$ In her Petition for Reinstatement, 1912 (see note 2), she claimed that she had been employed as an assistant physician at the Gynaecological Clinic in Berlin for two years before she left Berlin for Travnik in December 1902. 
who personally took care of institutionalising official female physicians (26). ${ }^{6}$ Neumann kept pushing the supreme authority to extend the system of official female physicians across all $\mathrm{BH}$ districts. Neumann probably considered Einhorn a highly adequate candidate and invited her to apply for a never officially advertised position in Travnik (5). ${ }^{7}$ In February 1902, Einhorn applied to the AH provincial public health authorities in Sarajevo who, after scrutinising her credentials and police records concerning her political behaviour and moral conduct in St. Petersburg and Berne, recommended her appointment (4). As soon as Einhorn had acquired Austrian citizenship in Götzendorf, a village at Vienna's outskirts, she was appointed as a provisional female official physician of Travnik by decree on November 25, $1902(4,5)$. She left Berlin and arrived at Travnik on December 22, 1902, to work as an official female physician.

\section{Einhorn's Professional Activities as an Official Female Physician 1903 - 1904}

When Rosa Einhorn arrived at Travnik (Picture 4), the city had about 7000 inhabitants (including the present $\mathrm{AH}$ civil and military population),

${ }^{6}$ De Kállay died in office in 1903, and his successor Bilinski showed all the less interest in the matter that the academic education for women had meanwhile been established.

${ }^{7}$ Both Ctibor Nečas (1991: 105) and Barbara Martin (2018: 5) point at the fact that Einhorn left behind Carola Meyer (also Maier, Meier) Milobar, MD (1876-1945) who obviously had been promised (unofficially) the not yet created office of a female physician of Travnik (cf. ABH, ZMF 13246, November 19, 1900). Carola Meyer, the renowned Croatian gastroenterologist, was originally a German citizen who had grown up in Switzerland and finished her medical studies in Zurich. After marrying the Croatian conservative philosopher and politician Fran Milobar (1869-1945), she came to BH and worked as an assistant physician at the provincial hospital in Sarajevo. When Rosa Einhorn turned up as new candidate, Milobar's application as an official female physician was rejected, because she was considered "too academic" and did not speak the "popular language". Milobar left BH, obtained an imperial special permission to practice as a female physician in Austria and opened a private medical office in Zagreb in 1906. Sertić K. Karola Maier Milobar - The first female doctor in Croatia [in Croatian] [updated 2019 March 19; cited 2020 July 17]. Available from https://www.zeneimediji.hr/ karola-maier-milobar-prva-lijecnica-u-hrvatskoj/ who were $42 \%$ Muslim, 41\% Roman Catholic, 10\% Orthodox, and 7\% Israelite according to the $\mathrm{AH}$ Census of 1910 (27). Travnik served as an AH garrison with a military hospital and comprised a community-funded hospital with 44 hospital beds, relocated and enlarged in 1899 (28). Travnik, situated at an elevation of $514 \mathrm{~m}$, was BH's capital in the $18^{\text {th }}$ and early $19^{\text {th }}$ centuries and was considered an attractive place by the $\mathrm{AH}$ occupants.

Einhorn took her oath of office on December 23, 1902 and started to work without delay. As demonstrated by the mentioned daily press feature, she had established her outpatient ward within a few weeks of her arrival. According to her reports for the first half of 1903, she had been consulted by 554 local women for all kinds of disorders, and $55 \%$ of the women were Muslims (5). In the summer of 1903, she was called on her first official trip to the subdistricts of Bugojno, Jajce, Zenica, and Žepče and treated 520 patients (5).

Having just returned to Travnik, she was among the victims of a fire disaster caused by a spark jumping from a locomotive that destroyed the historic city of Travnik on September 3 and 10, 1903. More than 3000 residents were left homeless and sheltered in barracks, military tents, and rural emergency quarters $(7,29)$. Rosa Einhorn's outpatient ward burnt down (30), but her report suggests that she treated more women than ever from September to December in 1903. She apparently saw the disaster as an opportunity to examine and treat as many women as possible, although local women (of any religion) were probably unprepared to consult modern physicians, even if they were female.

The report indicates the incredible number of 2450 (female) patients, 1376 of whom Einhorn must have visited in their emergency quarters. Following the $\mathrm{AH}$ conceptualisation of her office, she preferentially 'targeted' Muslim women because her statistics indicate that two-thirds of her patients were Muslims (5). Additionally, she vaccinated 3260 persons in 1903 (5). Therefore, Einhorn proved to be the most effective AH official female physician ever; even Teodora Krajewska in Sarajevo did not treat more than a maximum of 1500 patients per year (27) 


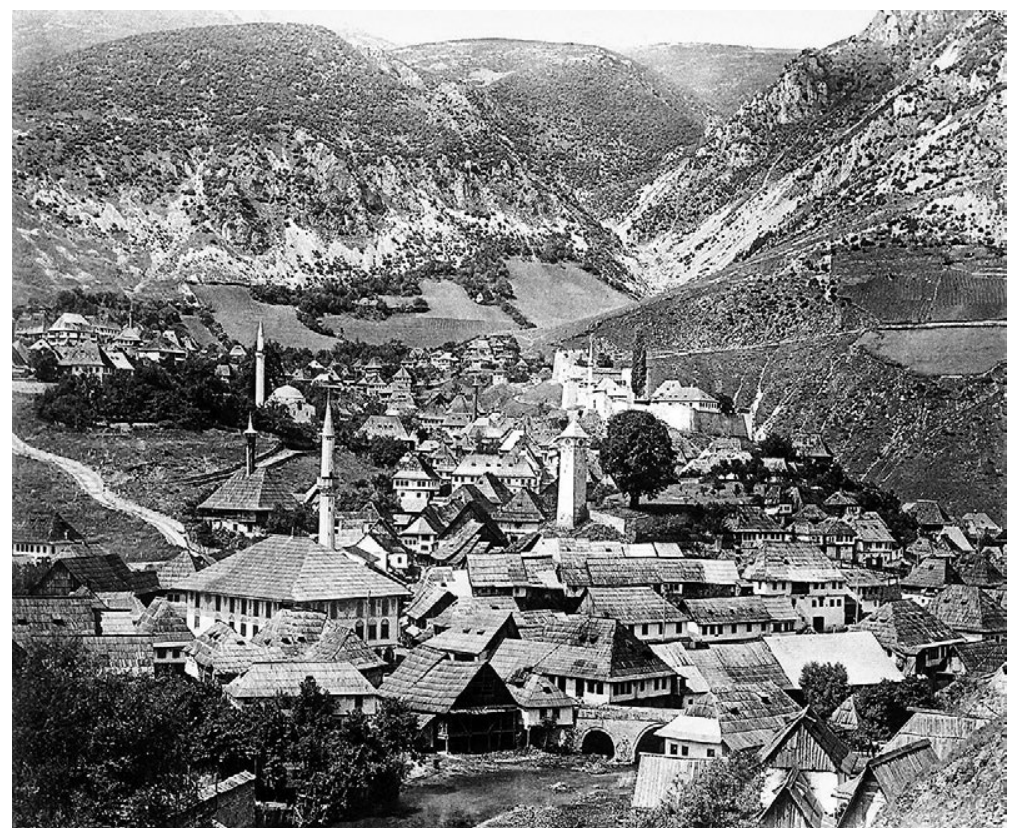

Picture 4. Travnik at the time when Rosa Einhorn started working there. Published with kind permission of the Museum of Travnik.

Einhorn's preserved report for the second quarter of 1904 again provided the extraordinary cyphers of 674 (female) patients treated for all kinds of disorders predominantly during her official trips from April to June (5). While her status had not been made permanent at the end of her provisory year in December 1903, it seems that the public health authorities informed her of her imminent dismissal in July 1904. The allegations brought against her bluntly stated that 'people disliked' her and that she lacked politeness and exceeded her competencies (5). Among others, she made herself unpopular by taking advantage of the emergency in Travnik to compel the local Muslim women to undergo medical examinations. Einhorn seems to have been bullied predominantly because of her alleged overzealousness, although she carried out her duties exactly according to the service description for AH female official physicians. Representing herself as a zealous moderniser in 1903 (1), she believed in female physicians' civilising mission in the sense of the top-down approach promoted by Teodora Krajewska $^{8}$ (31), the official female physician of Sarajevo.

${ }^{8}$ Fuchs B, Tahirović H. Teodora Krajewska: Medical Practitioner, Woman of Science, Polish Patriot and Feminist. Acta Med
This bullying was even less scrupulous due to Einhorn's engagement to Sigismund Bloch in late Autumn 1903 when the authorities informed her immediately that marrying a court official would not only result in her dismissal but a professional ban in her husband's judiciary district. ${ }^{9}$

Learning that she would be dismissed, Einhorn did not react in a well-conceived way. She applied for a two-month leave in the monarchy', from which she did not return until 1905. After visiting her sister in Vienna, Einhorn embarked for New York in Cuxhaven in mid-August and asked her superiors only at that point for an extension of her leave to attend a medical congress in the United States (5). Upon entering the United States, she stated that she was visiting her brother 'Prof. Dr. Max Einhorn' and did not plan to return. ${ }^{10}$ She participated as a guest in an international meeting of the US Association of Military Surgeons held in St. Louis, Missouri from October 10 to 15, 1904 (32, 33). Subsequently, Einhorn passed the state examination at Columbia University in New York, entitling her to practice as a physician in the United States and was employed at the Gynaecological Department of the University Hospital in St. Louis. ${ }^{11}$ As she admitted later, she had never had the intention to return at that point. In late 1904, the public health authorities sent her certificate of dismissal to the United States and gave her months-long absenteeism in $\mathrm{BH}$ as the main reason (5). Rosa Einhorn changed her mind and decided to return in spring 1905. She excused her long absence with a medical certificate

Acad. 2019;48(3):317-27. [cited 2020 Aug 12]. Available from: https://pubmed.ncbi.nlm.nih.gov/32124632/

${ }^{9}$ Einhorn's Petition for Reinstatement 1912, see note 2.

${ }^{10}$ New York Passenger Arrival Lists (Ellis Island), 1892-1924, database with images, Family Search, Rosa Einhorn, 1904. [cited 2019 Aug. 20]. Available from: https://familysearch. org/ark:/61903/1:1:JNMB-822

${ }^{11}$ Einhorn's Petition for Reinstatement 1912, see note 2. 
attesting that she had suffered from abdominal typhoid and its consequences (5). Back in Travnik, she commenced a long struggle for her reinstatement as an official physician in the district.

\section{Rosa Einhorn's Activities as a Private Physician, 1905-1912}

After Rosa Einhorn returned to Travnik in spring 1905, she married Sigismund Bloch at the end of the year ${ }^{12}$ and called herself from that point on 'Einhorn-Bloch'13. On October 30, 1906, she gave birth to a son, Hermann. As indicated by her involvement in a committee that sought to establish children's convalescent homes in Crikvenica on the Croatian Adriatic coast in 1910 (34), her son might have been of frail health.

In 1905, she obtained an imperial special permission to practise as a private physician with a Swiss diploma in $\mathrm{BH}$. Her petition was endorsed by the $\mathrm{BH}$ provincial public health authorities (5), and we might assume that, while still in the United States, she had been unofficially informed that she would be used, like Gisela Januszewská in Banja Luka, as a semi-official private physician. However, things turned out badly for Rosa Einhorn-Bloch. Her private practice seems to have been only moderately popular, as expected in a rural area. She was called upon for official syphilis eradication campaigning in $1908^{14}$ and 1909 (4) but declined participation in 1910 when she filed a petition to the provincial authorities stating that she should either be reinstated as an official female physician or be replaced (5).

In 1912, she directed a last appeal for either reinstatement 'or possibly any other position' to Governor Leon de Bilinski (1846-1923) personally because the provincial public health authorities had conditioned her possible reinstatement at that point on the accreditation of her Swiss diploma for Austria ('nostrification'). She asked the governor

\footnotetext{
${ }^{12}$ Ibidem.

${ }^{13}$ It was common that female professionals combined the father's name with the husband's name upon marriage. However, the authorities insisted on the reverse order, in this case "Bloch-Einhorn".

${ }^{14}$ Einhorn's Petition for Reinstatement 1912, see note 2.
}

to refrain from nostrification in her case, explaining that she had already spent five months volunteering at hospitals in Graz and Vienna to become considered but wished not to be separated any longer from her family in Travnik (Picture 5). ${ }^{15} \mathrm{Her}$ reemployment efforts as an official physician in $\mathrm{BH}$ and for accreditation in Austria proved to be in vain, however, and Rosa Einhorn-Bloch decided to leave Bosnia forever.

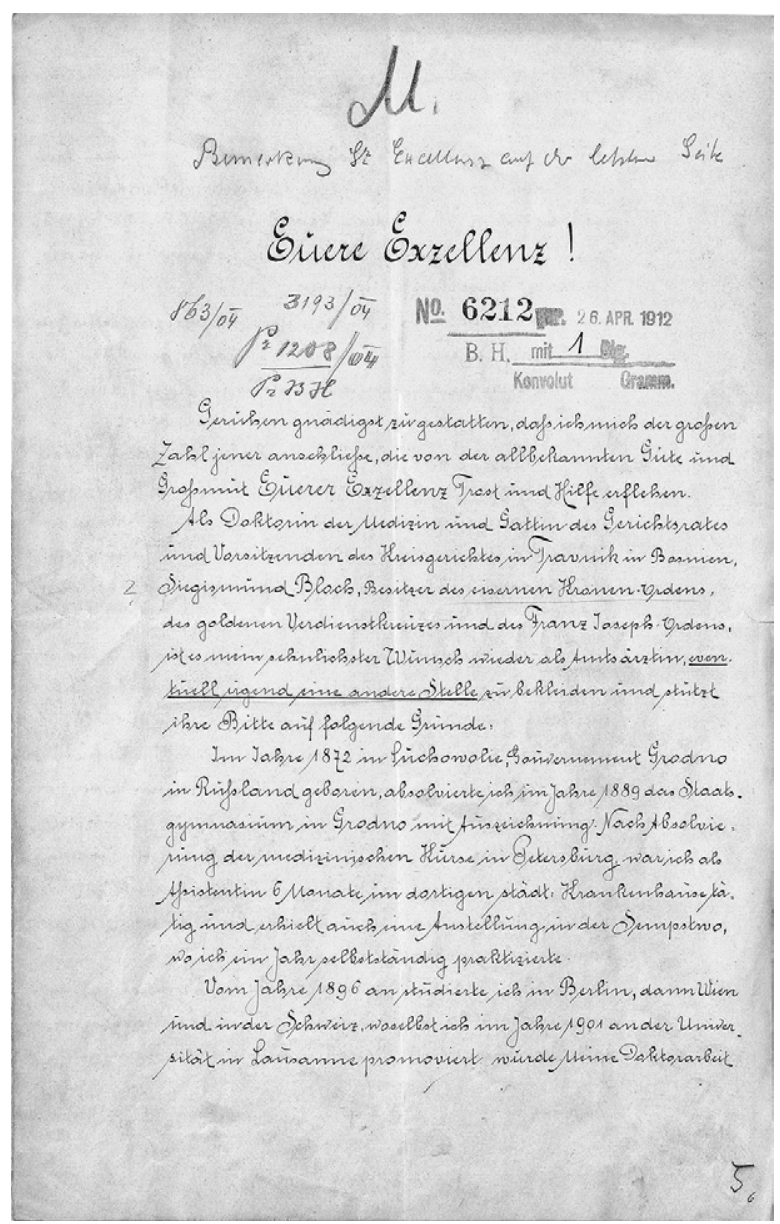

Figure 5. Rosa Einhorn's Petition for Reinstatement to Governor Leon de Bilinski from April 23, 1912. Source: Vgl. ABH, ZMF 6212, BH 1912, kut. 29 [cited 2020 Nov 2].

\section{Emigration to the United States}

At the end of 1912, Rosa Einhorn-Bloch's situation as a professional in the Austro-Hungarian Empire was desperate. She decided to move to the United

${ }^{15}$ Einhorn's Petition for Reinstatement 1912, see note 2. 
States and embarked with her son for New York in late March 1913. ${ }^{16}$ In the United States, she started to work as a physician in Newark, New Jersey in the New York metropolitan area in $1914 .{ }^{17}$ On March 30, 1914, her son Hermann died in a sanatorium in New York of 'lobar pneumonia' at the age of seven and was buried in Mt. Judah Cemetery in New York. ${ }^{18}$ Rosa Einhorn was still listed as a physician living in Newark, Peshine avenue in 1915. ${ }^{19}$ It is uncertain whether she ever returned to Travnik, although she returned to Europe during World War I. Martin's thorough archival research reveals that she was employed as an assistant physician in a mental asylum in Münsterlingen in Thurgau, Switzerland from April to November 1917 (5; note 149). Her husband joined her at this location for some weeks (ibid.).

Moreover, quite probably, the couple divorced at that point. When Rosa Einhorn took her passage to the United States in 1923, she called herself 'Einhorn' again and registered her status as single. ${ }^{20}$ She stated she was a Polish citizen and designated a sister-in-law, Mina Einhorn in Bialystok, as her next relative. She gave Cairo, Egypt as her latest permanent residence. ${ }^{21}$ Cairo is indicative

${ }^{16}$ Rosa Einhorn-Bloch, 1913; Hermann Einhorn-Bloch, 1913; New York Passenger Arrival Lists (Ellis Island), 1892-1924, database with images, Family Search. Available from: https://familysearch.org/ark:/61903/1:1:JJM4-QZH [cited Aug 16, 2019].

${ }^{17}$ Rosa Einhorn, 1950. United States Deceased Physician File (AMA), 1864-1968", database with images, FamilySearch. Available from: https://familysearch.org/ark:/61903/1:1: WDDR-GNZM [cited Sept 2, 2019].

${ }^{18}$ Herman Block [sic; recte: Bloch], New York City Department of Records \& Information Services; New York City, New York; New York City Death Certificates; Borough: Brooklyn; Year: 1914. (Ancestry.com. New York, New York, Index to Death Certificates, 1862-1948 Lehi, UT: 2020 [database online, cited Sept 7, 2020].

${ }^{19}$ Einhorn, Rosa MD 1915; Newark, New Jersey, City Directory, 1915 (Physicians, p. 1617). U.S., City Directories, 18221995. Provo, UT, USA: Ancestry.com Operations, Inc., 2011 [database on-line, cited 2020 Nov 15].

${ }^{20}$ See also Einhorn's Petition for Nationalization, cf. note 1.

${ }^{21}$ Rosa Einhorn, 1923. New York Passenger Arrival Lists (Ellis Island), 1892-1924, database with images, FamilySearch. [cited 2019 June 16]. Available from: https://familysearch. org/ark:/61903/1:1:JNQX-6ZG; https://familysearch.org/ ark:/61903/1:1:JNQX-6ZG that Rosa Einhorn may have considered settling in Palestine/Eretz Israel after the region had become controlled by the British in 1917 and obtained a mandatory status in 1920. The British Mandate administration granted at least a physician's license 'No 140' to Rosa Einhorn, who was living in Tel Aviv in the 1930 s. $^{22}$

After immigrating to the United States in 1923, "Rosa Einhorn, MD" is recorded in the Newark City directories at an address on Clinton avenue from 1924 to $1928 .{ }^{23}$ She officially practised as a physician in Newark until 1929 and subsequently moved to Manhattan, New York. ${ }^{24}$ The 1930 US census data show her as a 'roomer' in Manhattan. ${ }^{25}$

She probably left for Mandatory Palestine in 1930 or during the early 1930s, after receiving US citizenship in February 1929. Her name appears in an address booklet of physicians in Tel Aviv, ${ }^{26}$ which was a rapidly growing city at the time due to middle-class immigration from Soviet Russia, Austria, Hungary, and Germany. She shared an address with a physicians' couple from Soviet Russia,

${ }^{22}$ Rosa Einhorn. List of Doctors, Pharmacists, Dentists and Midwives who have been licensed (מיחקור, םיאפור לש המישר) פווישירב וכז תודליימו םייניש יאפור, (וּרוע), 1936; 1938; 1939. Medical Practitioners 1921-1948 (1948-1921) database, page 17, IGRA number 8234 (original records: National Library of Israel (תימואלה היירפסה) [on-line database; cited on 2020 Dec 7].

${ }^{23}$ Rosa Einhorn MD. Newark, New Jersey, City Directory, 1925; 1926; 1927; 1928. Ancestry.com. U.S., City Directories, 1822-1995 Provo, UT, USA: Ancestry.com Operations, Inc., 2011 [database on-line; cited 2020 Nov 19].

${ }^{24}$ Rosa Einhorn, 1950. United States Deceased Physician File (AMA), 1864-1968, database with images, Family Search (https:/familysearch.org/ark:/61903/1:1:WDDR-GNZM: 2 September 2019). [cited 2020 Nov 5]. Available from: https:// www.familysearch.org/ark:/61903/3:1:3QS7-99QG-599Y-W? $\mathrm{i}=322 \& \mathrm{cc}=2061540$ \&personaUrl $=\% 2 \mathrm{Fark} \% 3 \mathrm{~A} \% 2 \mathrm{~F} 61903 \% 2$ F1\%3A1\%3AWDDR-GNZM.

${ }^{25}$ Ross Einhorn [sic]; 1930; Manhattan, New York, New York; Page: 28A; Enumeration District: 0443; FHL microfilm: 2341291. Ancestry.com. 1930 United States Federal Census Provo, UT, USA: Ancestry.com Operations Inc, 2002. Original data: United States of America, Bureau of the Census. Fifteenth Census of the United States, 1930. Washington, D.C.: National Archives and Records Administration, 1930. T626, 2,667 rolls [database on-line; cited 2020 Nov 18].

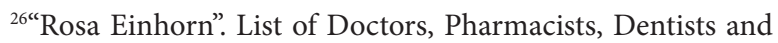
Midwives who have been licensed (מוריהקור, סיאפור לש המישר) זוישירב וכז תודליימו םייניש יאפור, 20. 


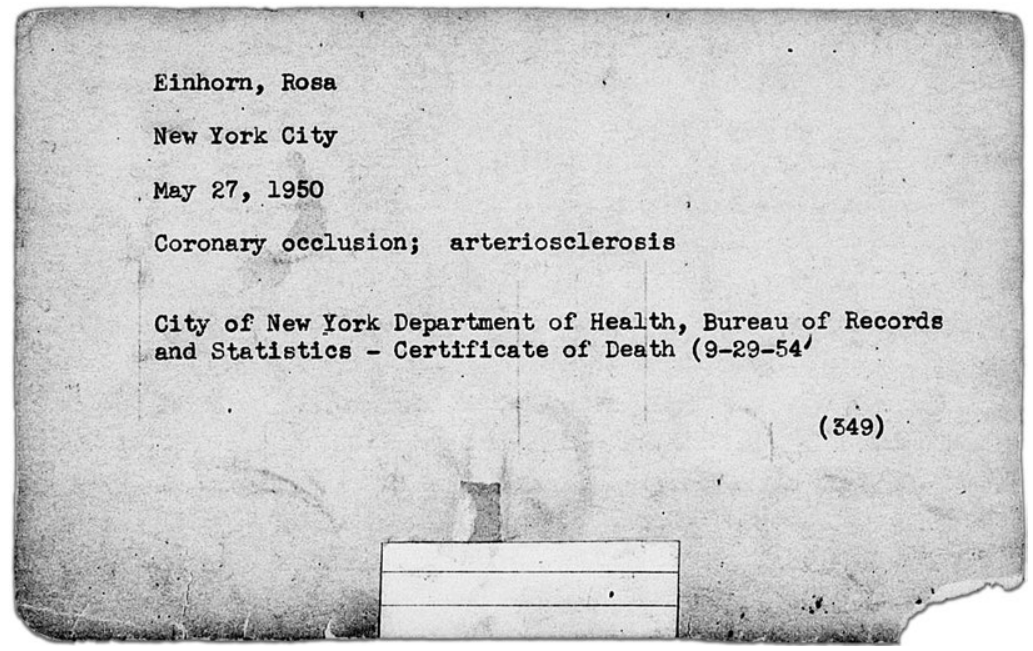

Picture 6. Rosa Einhorn's index card; United States Deceased Physician File (AMA), 1864-1968. Source: FamilySearch, database with images. [cited 2019 Sept 2]. Available from: https://familysearch.org/ark:/61903/1:1:WDDR-GNZM this plan and settled in Manhat$\tan ^{29}$ As indicated in an obituary for Max Einhorn, 'Dr. Rosa Einhorn' spent much time with her widowed brother, providing him 'considerable comfort until she also died' (14). Rosa Einhorn, MD, died on May 27, 1950, of coronary occlusion and was buried on May 28 in Mount Judah Cemetery in Queens, New York (Picture 6). ${ }^{30}$

\section{Concluding Remarks}

After qualifying as a learned midwife' in St. Petersburg in 1892, Rosa Einhorn left no stone unSimon and Esther Baskin Einhorn, who practised at municipality-funded Tel Aviv 'Health House' founded in 1932.

The "Health House" was one of three venues for sexual consultation as conceptualised by the European contemporaneous East-Central European movement for sexual reform $(35,36)$ that, while aiming at popularising birth control, also pursued a civilising mission vis-à-vis the traditional ("Mizrahi") populations (37). Rosa Einhorn was an experienced expert in this matter, though it is not clear whether she regularly practised or volunteered at the Tel Aviv 'Health House' or was even among its organisers. When the movement for sexual reform came to a halt in the run-up to World War II, Einhorn left the country in 1938 for the United States. ${ }^{27}$

In New York, she asked the local public health authorities about the possibility of obtaining a license for California. ${ }^{28}$ However, she abandoned

\footnotetext{
${ }^{27}$ Rosa Einhorn (1938); New York, New York Passenger and Crew Lists, 1909, 1925-1957. Havre, France, New York, New York, United States, NARA microfilm publication T715 (Washington, D.C.: National Archives and Records Administration, n.d.). [Cited 2019 June 17]. Available from: https://www.familysearch. org/ark:/61903/3:1:33S7-95NZ-9R5N?i=65\&cc=1923888 „Rosa Einhorn, MD“ had travelled between Tel Aviv, Europe and the U.S. also in 1934 and 1937 (ibidem).

${ }^{28}$ Rosa Einhorn, 1950. “United States Deceased Physician File
}

turned to acquire her MD. Her brother, the reputed US gastroenterologist Max Einhorn, probably encouraged and supported her medical studies in St. Petersburg (where women were not permitted to graduate) and, subsequently, in Berlin, Vienna, Berne, and Lausanne. Her enthusiasm to augment her medical knowledge is outstanding and related to her idea that modern medicine and physicianmodernisers might change the world for the better.

In fulfilling this mission, she developed an extraordinary degree of mobility and determination. Though she may have settled as a physician in the United States after being dismissed as an official female physician in Bosnia in 1904, she preferred to continue her work in Bosnia. Moreover, she also preferred working in Mandatory Palestine on modernising Mizrahi women over her practice in the United States. Having received her doctorate

(AMA), 1864-1968," database with images, FamilySearch. [cited 2020 Sept 2]. Available from: https://familysearch.org/ ark:/61903/1:1:WDDR-GNZM

${ }^{29}$ Rosa Einhorn MD; New York, New York, City Directory, 1942; 1943; 1946; 1948; Ancestry.com. U.S., City Directories, 1822-1995. Provo, UT, USA: Ancestry.com Operations, Inc., 2011. [database on-line; cited 2020 Nov 16].

${ }^{30}$ Rosa Einhorn, 1950; United States Deceased Physician File (AMA), 1864-1968", see note 20; Rosa Einhorn, U.S., Find A Grave Index, 1600s-Current [Provo, UT, USA: Ancestry.com Operations, Inc., 2012 [database on-line; cited 2020 Nov. 17]. 
from the University of Lausanne in 1901, Rosa Einhorn's employment as an official female physician in Travnik was sponsored by the Bosnian government in Vienna. She worked 18 months as a provisory officer in Travnik and the Travnik district and treated 3125 female patients within 15 months in 1903 and 1904. Therefore, Einhorn was the most efficient female health officer ever but aroused the 'dislike' of the local authorities and physicians not least for that reason. After she reacted to the threat of dismissal by 'escaping' to the United States, she was dismissed in November 1904 because of her months-long absenteeism. Einhorn returned in 1905 to marry Sigismund Bloch, a locally settled AH judiciary, which made her situation even more difficult because the $\mathrm{AH}$ supreme authority did not approve of the wife of an Austrian judge working in the same judiciary district as her husband. However, she petitioned successfully for her right to practise privately in $\mathrm{BH}$ in 1905 and was supported by the provincial public health authorities who, regarding syphilis eradication campaigning, insisted on the presence of a female physician on site. After Rosa Einhorn had been called on for syphilis eradication in 1908 and 1909, she appealed in vain for her reinstatement as an official physician and for the accreditation of her Swiss diploma in Austria. She left Bosnia for the United States in 1913 but emigrated to the United States only in 1923. Practising as a physician in Newark in the 1920s, Einhorn left the United States to work as a sexual reform consultant and physician in Tel Aviv in Mandatory Palestine. She returned to the United States because of the decline of the sexual reform movement in 1938 and settled in Manhattan, New York, where she died and was buried in May 1950.

Authors' Contributions: Conception and design: BF and HT; Acquisition, analysis and interpretation of data: BF and HT; Drafting the article: BF and HT; Revising it critically for important intellectual content: HT and BF; Approved final version of the manuscript: BF and HT.

Conflict of Interest: The authors declare that they have no conflict of interest.

\section{References}

1. Anon. Beim Fräulein Doktor. Die ärztliche Behandlung der Mohamedanerinnen. In Neuigkeitsweltblatt. 1903; February 19.

2. Note [in German]. Neues Wiener Journal. 1902;3275, December 7:.7. (see also notes e.g. in: Mährisches Tagblatt. 1902;281, December 6:7; Oesterreichische Zeitschrift für Pharmacie. Zeitschrift des Allgemeinen Apotheker-Vereins. 1902;40(51):522.

3. Steiner L, editor. Address book of civil and military physicians, pharmacists, hospitals, civil and military medical institutions as well as health resorts and spas in Austria, Hungary, Bosnia and Herzegovina [in German]. 1905/06;5. Vienna: Georg Szelinski, Vienna 1905.

4. Nečas C. Among Muslim Women. The activities of the female health officers in Bosnia and Herzegovina, 18921918 [in Czech]. Brno: Masaryk University, 1992, p. 102-8.

5. Martin B. As female physician in Bosnia and Herzegovina: Rosa Bloch-Einhorn's professional activities in Travnik, 1902-1917(?) [in German]. [cited 2020 Oct. 17]. Available from: https://www.scribd.com/document/386555172/AlsArztin-in-Bosnien-Herzegowina-zur-Tatigkeit-RosaBloch-Einhorns-in-Travnik-von-1902-bis-1917.

6. Omanić A, Dodig-Karaman Ž. Serdarević M, Kabiljo M. The contribution of Jewish health care professionals to the development of health care in Bosnia and Herzegovina [in Croatian]. Acta med-hist. Adriat. 2008;6(1):41-54.

7. Konforti J. Jews of Travnik [in Bosnian]. [cited 2020 Oct. 12]. Available from: https://www.jews.ba/post/12/JevrejiTravnika.

8. Yad Vashem 1988. “Travnik”. Translation from Pinkas hakehilot; entsiklopediya shel ha-yishuvimle-min hivasdam ve-ad le-aher shoat milhemet ha-olam ha-sheniya: Yugoslavia/Encyclopaedia of Jewish Communities: Yugoslavia, edited by Zvi Loker, Jerusalem: ad Vashem, 1988, pp. 162165. [cited 2020 Oct. 14]. Available from: https://www.jewishgen.org/yizkor/Pinkas_Yugoslavia/yug_00162.html.

9. Anon. The first Jews in Travnik [in Bosnian]. [cited 2020 Oct. 12]. Available from: https://www.jews.ba/post/11/ Prvi-Jevreji-u-Travniku.

10. Einhorn M. Wolkovisker Yizkor Book (Volkovysk. The Trilogy, Part I), New York: Dr. Moses Einhorn, 1949, p. 1.

11. Sefer Sukhovola / Suchovola (Memorial Library of Jewish Communities), Editorial board: Kh. Shteynberg, M. Vonkhotsker, Y. Levin, Y. Tsaban. Jerusalem/Tel-Aviv: 1957. Translation by Peter Zinn, pp. 25-27. [cited 2019 June 20]. Available from: https://www.jewishgen.org/Yizkor/suchowola/suc019.html.

12. "Einhorn, Max". Biographical Sketches of Jews Prominent in the Professions etc., in the United States. In: The American Jewish Yearbook, vol. 6 (September 10, 1904, to September 29, 1905/5665). p. 52-213; p. 84. 
13. Max Einhorn. Autobiography [in German]. In: Grote L.R. (ed). Die Medizin der Gegenwart in Selbstdarstellungen. Leipzig: Verlag von Felix Meiner; 1929. p. 1-24.

14. Andresen AF. In memoriam Dr. Max Einhorn, 1862-1953. Gastroenterology. 1954;26(1):121-2. PMID: 13117226.

15. Bockus, HL. The Einhorn Story. Historical Profiles. Gastroenterology 1978;74:949-50. PMID: 346433.

16. Einhorn, Rosa, Matrikel-No.: 8166, vol. BB IIIb 1161. Matrikelbücher der Universität Bern 1805-1925. [cited 2020 Nov. 17]. Available from: http://www.archivwissenschaft.ch/uab/suchresultate.php.

17. Neumann D. Female Students from the Russian Empire in Switzerland, 1867-1914 [in German]. Zürich: Hans Rohr, 1987.

18. Hirsch L. From the Shtetl to the Lecture Hall: Jewish Women and Cultural Exchange. Lanham: University Press of America; 2013.

19. Freidenreich HP. Jewish Women Physicians in Central Europe in the Early Twentieth Century. Contemporary Jewry. 1996;17(1):79-105.

20. Freidenreich HP. Female, Jewish, and Educated: The Lives of Central European University Women. Minneapolis: Indiana University Press; 2002.

21. Offer M. Introduction: Jewish Women Medical Practitioners in Europe before, during and after the Holocaust. Nashim. 2020;36:10-21.

22. Grossmann A. Motherhood and modernity: German women doctors in the Weimar Republic, during the Nazi era, in exile and in the post-war period [in German]. In: Institut für Sozialforschung Frankfurt, ed. Geschlechterverhältnisse und Politik. Frankfurt a.M.: Edition Suhrkamp; 1994. p. 288-309.

23. Einhorn R. Beitrag zur Kenntniss der Unterschenkelfracturen. Berlin: Druck L. Schumacher, 1901 (Université de Lausanne: med. thèse, 1900). [cited 2020 Nov. 17] Available from: https://db-prod-bcul.unil.ch/dbbcu/theses/ thesaut.php.

24. Einhorn R. For knowledge of lower leg fractures [in German]. Archiv für klinische Chirurgie. 1901;64(4):791-848.

25. "Einhorn, Mlle. Rosa, Russe". Catalogue des étudiants de l'université de Lausanne, No. 21. Année universitaire 1900-1901, semestre d'hiver. Lausanne: Imprimerie J. Couchoud. p. 14.
26. Fuchs B. Orientalising Disease. Austro-Hungarian Policies of 'Race', Gender, and Hygiene in Bosnia and Herzegovina, 1878-1914. In: Trubeta S, Turda M, Promitzer C, eds, Health, Hygiene and Eugenics in Southeastern Europe until 1945. Budapest: CEU Press; 2011. p. 57-85.

27. Die Ergebnisse der Volkszählung in Bosnien und der Hercegovina vom 10. Oktober 1910, ed. by Bosna Wilāyet/ Landesregierung für BH. Sarajevo: Landesdruckerei; 1912.

28. Landesregierung für Bosnien und die Hercegovina (ed): Public Health in Bosnia and Herzegovina 1878-1901 [in German]. Sarajevo: Landesdruckerei; 1903. p. 246.

29. Anon. Big Fire in Bosnia [in German]. Feuerwehr-Signale. 1903;24 (September 20):17.

30. Anon. The Fire Disaster in Travnik [in German]. Agramer Zeitung. 1903;204 (September 7):5-6. (p. 6: Einhorn's name is given incorrectly as "Eichhorn").

31. Krajewska T. The experience of a female physician's in Dolnja Tuzla (Bosnia) [in French]. In: Schoenflies R, Morgenstern L et al., editors. Der Internationale Kongress für Frauenwerke und Frauenbestrebungen in Berlin, 10. bis 26. Sept. 1896. Berlin: Hermann Walther; 1897. p. 185-90.

32. Meeting of the Association of Military Surgeons St. Louis, October 10-15, 1904. In: Annual Report of the Surgeon General of the Public Health and Marine Hospital Service of the United States for the Fiscal Year 1905. Washington Governmental Printing Office 1906 (Treasury Department Doc. No. 2427, Public Health and Marine Hospital Services). p. 229-31.

33. Steiner J. The international congress of military surgeons in St. Louis in October 1904 [in German]. Militärarzt. 1905;(39):81-3.

34. Anon. A children's sanatorium and recreation home in Crikvenica [in German]. Die Zeit. 1910;2811;(July 23) 1910:11.

35. Grossmann A. Reforming Sex. German Movement for birth control and abortion reform, 1920-1950. New York et al.: Oxford University Press; 1995.

36. Lehner K. Proscribed Interventions: Social democratic efforts to reform the abortion regulations in the interwar period [in German]. Vienna: Picus; 1989.

37. Liat K. Sexology in the Yishuv. The Rise and Decline of Sexual Consultation in Tel Aviv, 1930-39. International Journal of Middle East Studies. 2010;42:231-49; p. 238-40. 